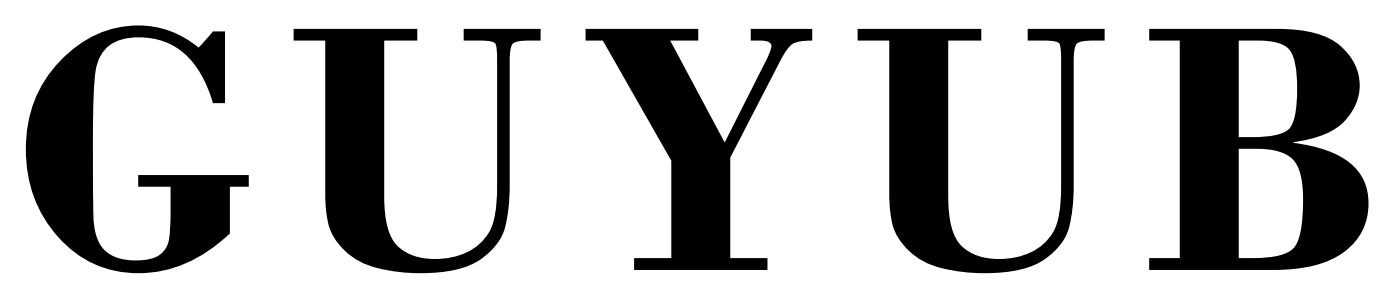

Journal of Community Engagement

Vol. 2, No. 2, Agustus 2021

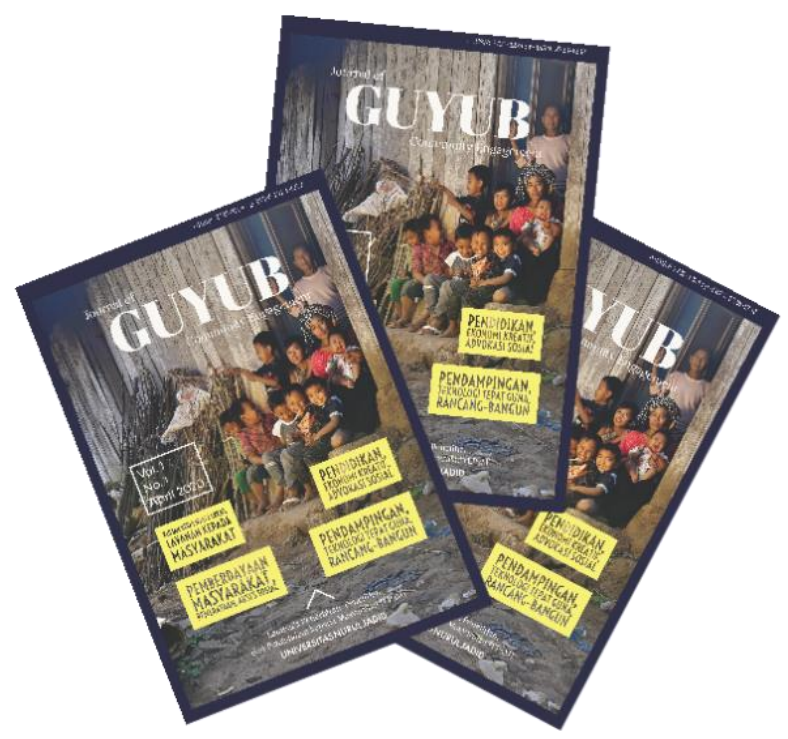

PKM Pendampingan Santri Nurul Jadid melalui Gerakan Literasi Cerdas dalam Membentuk Komunitas Pelajar Berkarakter Islam di Pondok Pesantren Nurul Jadid

Faizatul Widat, Afita Khoirun Nisa', Wardatul Habibah, Wahibatul Mas'ula, Nikmatul Hosniah, Jamilatul Masnunah, Hamidah

PKM Penyuluhan Pembuatan dan Penyemprotan Disinfektan (PEPEDES) sebagai Upaya Pencegahan Covid-19 di Desa Kalikajar Kulon Probolinggo

Fahrudin, Ayu Midyah Putri, Abdul Hamid Isnaini, Abdul Latif Isnaini, Duwi Handika Okta Rotama, Rosi Nurjannah, Suharno

PKM Pendampingan Penyusunan Kurikulum Sekolah Ramah Anak pada Taman Kanak Kanak (TK) Az-Zainiyah II Paiton Probolinggo

Abu Hasan Agus R, Durratul Mashunah, Hostin, Hilyah Mashunah, Siti Rahayu, Atik Hikmatuz Zakiyah 


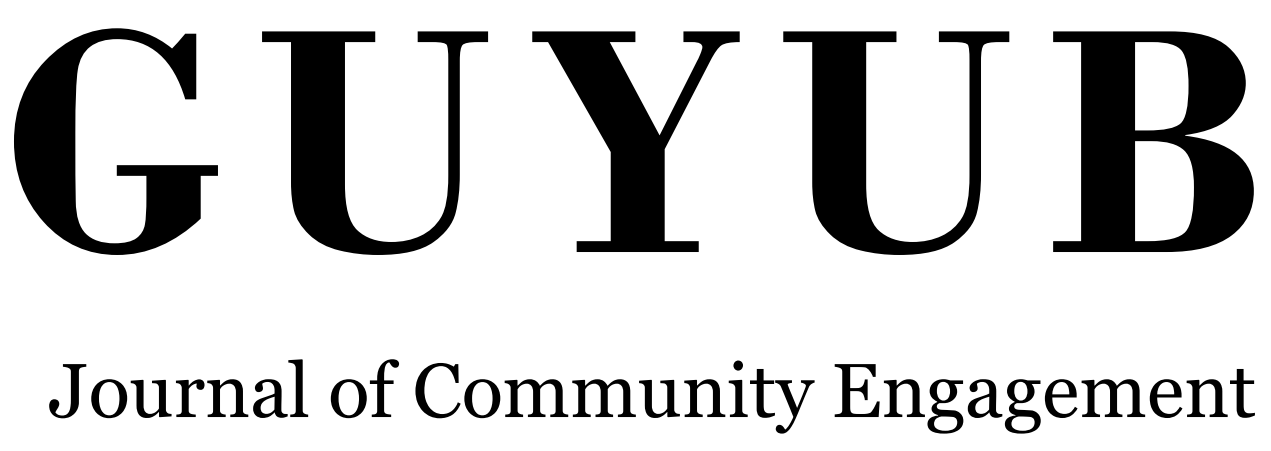




\section{G U Y U B}

\section{Journal of Community Engagement}

Vol. 2, No. 2, 2021

\section{Editor in Chief}

Achmad Fawaid, (SCOPUS ID: 57214837323)

\section{Managing Editors}

Hasan Baharun, (ID SCOPUS : 57200983602)

Sugiono Sugiono, (SCOPUS ID : 57199578160)

Ismail Marzuki, (SCOPUS ID: 57201500245

Subhan Rachman, (SCOPUS ID: 57192937912)

Nurul Huda, (SINTA ID: 6119615)

Syamsuri, (SINTA ID: 6116825)

Ridhatullah Assya'bani, (SINTA ID: 6200862)

\section{Peer Reviewers}

Miftahul Huda, (SINTA ID: 6171566), University of Antwerp, Belgium Achmad Naufal Irsyadi (SINTA ID: 6704870), Universitas Nurul Jadid, Indonesia Sukamto Sukamto, (SINTA ID: 5979034), Universitas Widya Gama Malang, Indonesia Deny Utomo, (SINTA ID: 6016108), Universitas Yudharta Pasuruan, Indonesia Fariz Alnizar, (SCOPUS ID: 6659824), UNUSIA Jakarta, Indonesia Fuad Rahman, (SCOPUS ID: 57201474778), UIN Sulthan Thaha Saifuddin Jambi, Indonesia Saifuddin Zuhri Qudsy, (SCOPUS ID: 57213595165), UIN Sunan Kalijaga Yogyakarta, Indonesia Akhmad Anwar Dani, (SINTA ID: 14305), IAIN Surakarta, Indonesia Maufur Maufur, (SINTA ID: 5989329), IAIN Kediri, Indonesia Siti Mahmudah Noorhayati, (SINTA ID: 6726997), IAIN La Roiba Bogor, Indonesia Busro Busro, (SCOPUS ID: 57205022652), UIN Sunan Gunung Djati Bandung, Indonesia Akmal Mundiri, (SCOPUS ID: 57205059378), UNUJA Probolinggo, Indonesia

\section{Section Editor}

Ahmad Zubaidi, Universitas Nurul Jadid, Probolinggo, Indonesia 
GUYUB: Journal of Community Engagement is a multidisciplinary journal which aims to disseminate the conceptual thoughts and research results in the area of community service. This journal focuses on the main problems of the community engagement areas, such as (1) training, marketing, appropriate technology, design; (2) student community services; (3) community empowerment, social access; (4) education for sustainable development, etc.

GUYUB: Journal of Community Engagement is published three times a year (April, August, December) by Lembaga Penerbitan, Penelitian, dan Pengabdian kepada Masyarakat (LP3M) Universitas Nurul Jadid, Paiton, Probolinggo, Jawa Timur, Indonesia.

Editorial Office:

GUYUB: Journal of Community Engagement

Lembaga Penerbitan, Penelitian, dan Pengabdian kepada Masyarakat (LP3M) Universitas Nurul Jadid, Paiton, Probolinggo, Jawa Timur, Indonesia 67291.

Phone: 088830 77077, Hp: 082318007953

Email: jurnal.guyub@gmail.com

Website: https://ejournal.unuja.ac.id/index.php/guyub/index 


\section{Tables of Content}

178-191

PKM Pendampingan Santri Nurul Jadid melalui Gerakan Literasi Cerdas dalam Membentuk Komunitas Pelajar Berkarakter Islam di Pondok Pesantren Nurul Jadid

Faizatul Widat, Afita Khoirun Nisa', Wardatul Habibah, Wahibatul Mas'ula, Nikmatul Hosniah, Jamilatul Masnunah, Hamidah

192-201

PKM Pelatihan Deep-Listening untuk Meningkatkan Kemampuan Berbahasa Inggris Santri Nurul Jadid Durratul Hikmah, Taufiqur Rahman, Irfan Wahyudi, Nur Hayati, Ahmad Zainullah, Kuni Zakiya Maskuroh

$202-210$

PKM Pendampingan Speaking Skill dengan Metode TROPIG di Wilayah Al Hasyimiyah Pondok Pesantren Nurul Jadid

Syaiful Islam, Nur Azizah, Rifdatul Qomariyah, Anis Fitria, Nurul Hamidah, Masrufah Masrufah

\section{1-224}

PKM Penyuluhan Pembuatan dan Penyemprotan Disinfektan (PEPEDES) sebagai Upaya Pencegahan Covid-19 di Desa Kalikajar Kulon Probolinggo

Fahrudin, Ayu Midyah Putri, Abdul Hamid Isnaini, Abdul Latif Isnaini, Duwi Handika Okta Rotama, Rosi Nurjannah, Suharno

225-232

PKM Pelatihan Pengisian Pengajuan Izin Operasional Taman Pendidikan Al-Quran secara Online Moh Jasri, Muhammad Romdloni, Mohammad Akmalor Riski, Nurul Hidayatullah, Muhammad Hasan Andika, Yogi Angga Praditya, Syukron Khafi, Shancen Ammabiel

\section{3-249}

PKM Pelatihan Pemanfaatan E-Learning Berbasis Teknologi Berbasis Platform Google Classroom bagi Guru Madrasah Ibtidaiyah Nurul Mun'im (MINM) Paiton Probolinggo

Feriska Listrianti, Nur Ika Sari, Siti Khomariya, Huswatun Hasanah, Millatun Hanifah, Deviyatul Hasanah

250-264

PKM Pelatihan Tutor Lembaga Kebahasaan Az-Zainiyah melalui Game Islami untuk Meningkatkan Keterampilan Berbicara Bahasa Inggris

Bradhiansyah Tri Suryanto, Nur Hasanah, Nuril Diar Anas, Sri Waliyul Hasanah, Syaiful Syaiful, Lia Umami

\section{5-275}

PKM Deteksi Dini Kelainan Tumbuh Kembang dengan Skrining Denver II dan Health Education di Taman Pendidikan Anak Shaleh Nurul Jadid Paiton Probolinggo

Zainal Munir, Zainul Hasan, Siti Nur Kholishoh, Melinia Akhirul Fitri 
PKM Habituasi Nilai-Nilai Keagamaan melalui Kegiatan Rohani DITABERHAMAN dalam Menciptakan Kesalehan Sosial di Pondok Mahasiswi (POMASI) Nurul Jadid Paiton Probolinggo

Zakiyah BZ, Ana Muthmainnah, Aminatuz Zuhriyah, Hamidah Hamidah, Miftahul Jannah, Wardatus Sholihah, Elok Nafiqoh

293-302

PKM Diversifikasi Ragam Produk Olahan Berbahan Dasar Ikan Teri sebagai Upaya Peningkatan Ekonomi Masyarakat Paiton Probolinggo

Saifuddin, Andre Dimas Fernando Putra, Moch Sofyan, Fadhlur Rohman, Mohammad Hasan Ainul Yaqin, Nailis Saadah Ali

303-312

PKM Pendampingan Penyusunan Kurikulum Sekolah Ramah Anak pada Taman Kanak Kanak (TK) AzZainiyah II Paiton Probolinggo

Abu Hasan Agus R, Durratul Mashunah, Hostin Hostin, Hilyah Mashunah, Siti Rahayu, Atik Hikmatuz Zakiyah

\section{3-325}

PKM Pelaksanaan Kegiatan Ekstrakurikuler Keagamaan dalam Membangun dan Mengembangkan Bakat dan Minat Santri pada Bidang Keagamaan di Madrasah Tsanawiyah (MTs) Nurul Jadid Probolinggo

Abdullah, Habibaturrohmah Habibaturrohmah, Halimatus Sakdiyah, Aisyah Amini, Putri Yunita Sari, Lilis Sulistiawati, Fitriyatun

326-341

PKM Sosialisasi Aplikasi Edmodo sebagai Alternatif Media Pembelajaran Daring di Madrasah Ibtidaiyah (MI) Az-Zainiyah II Paiton Probolinggo

Niken Septantiningtyas, Suhairiyah Suhairiyah, Fadilatul Hasanah, Umatuz Sholihah

$342-350$

PKM Pendampingan Pelatihan Penulisan Karya Tulis IImiah dalam Meningkatkan Kompetensi Guru di Madrasah Tsanawiyah (MTs) Nurul Jadid Paiton Probolinggo

Musolli Ready, Moh. Amir Kholili, Moh. Abd Mu'iz, Jefri Jefri, Moh. Agus, Moh. Ridwan Kamil

$351-360$

PKM Literasi Penguatan 3-M (Memakai Masker, Mencuci Tangan, dan Menjaga Jarak) Melalui Metode Storytelling di Pondok Pesantren Nurul Jadid Probolinggo

Mohammad Sofyan Adi, Dina Nur Faizah, Kamelia Yulia Novita, Robiatul Adawiyah, Ulfatul Nimatillah, Nuriah Waizul Romdani

361-368

PKM Pendampingan Pembelajaran Materi Bangun Datar dengan Billingual LED Running Text di Madrasah Ibtidaiyah (MI) Az-Zainiyah II Paiton Probolinggo

Nur Hamid, Muhammad Faiz Nailun Ni'am, Cahyu Guswita, Saiful Islam, Silviana Qomariyah, Siti Fatimah, Siti Khoifah

369-383

PKM Pendampingan Literasi Business Plan untuk Meningkatkan Pengetahuan dan Keterampilan Berwirausaha Santri Pesantren Nurul Jadid Mohammad Syaiful Suib, Yoviana Fitri, Lailatus Sa'adah, Nuril Fitriani, Widad Ulfatul Mawaddah Hadi, Siti Aisyah, Isna Shifah 
384-403

PKM Penanaman Karakter Berbasis Keagamaan bagi Warga Binaan Rumah Tahanan Kelas II. B Kraksaan Probolinggo Jawa Timur

Ahmad Fawaid, Muhammad Zaimul Millah, Achmad Naufal Baidawi, Siti Arofah, Nur Khofifah, Elmiyatus Soliha, Syukron Jazila, Rif'ah Hasanah, M Zainuddin

404-416

PKM Pendampingan Menghafal Al-Quran dengan Metode An-Nur pada Siswa Kelas X IPA Tahfidz Madrasah Aliyah Nurul Jadid Paiton Probolinggo

Abdurrahman, Indriani Putri Ayu Lestari, Lailia Mutmainnah, Hakimatus Sailah, Ika Fitri Anwar, Sofiya Mauliza, Nadya Afkarina

417-423

PKM Peningkatan Pendapatan pada Bidang Keputrian Wilayah Az-Zainiyah Pondok Pesantren Nurul Jadid melalui Strategi Pemasaran Berbasis Web

Anis Yusrotun Nadhiroh, Dina Wahyuni Suciati, Dzurrotun Nafila, Eva Nurmaliya, Nabila Maulidir Roziqina Fara 


\title{
PKM Literasi Penguatan 3-M (Memakai Masker, Mencuci Tangan, dan Menjaga Jarak) Melalui Metode Storytelling di Pondok Pesantren Nurul Jadid Probolinggo
} Mohammad Sofyan $\mathrm{Adi}^{1}$, Dina Nur Faizah' ${ }^{2}$, Kamelia Yulia Novita ${ }^{3}$, Robiatul Adawiyah ${ }^{4}$, Ulfatul Nimatillah ${ }^{5}$, Nuriah Waizul Romdani ${ }^{6}$

\author{
Universitas Nurul Jadid $1,2,3,4,5,6$
}

\{sofyanadi@unuja.ac.id ${ }^{1}$, dinanurfaizah@gmail.com ${ }^{2}$, kamelianovita01@gmail.com ${ }^{3}$, robiatula544@gmail.com ${ }^{4}, \underline{\text { abelulfa886@gmail.com }}$,, nuriramdani877@gmail.com\}

Submission: 2021-07-03 Received: 2021-08-18 Published: 2021-08-31

\begin{abstract}
Keywords:
3M Literacy,

Story telling,

Female

students

Abstract. One of the fundamental problems causing the widespread spread of COVID-19 is the low number of scientific literacy among female students. The inability of female students to understand the urgency of scientific terms makes them ignorant, lacks a sense of awareness of themselves and their environment in maintaining cleanliness and health and tends to be apathetic towards approaches to alleviating covid 19. Previously, understanding of biological, medical and epidemiological terms was optional for each person. Meanwhile, in the current crisis, as a step to anticipate and prevent the spread of COVID-19, it is very dependent on collective awareness that knowledge related to this can mean a choice between life or death, for oneself and for others. Therefore, it is necessary to have an intense and innovative approach in educating the community, especially female students in the Western Region of the Nurul Jadid Islamic Boarding School to always remember the $3 \mathrm{M}$ (Wearing masks, washing hands, keeping distance). The method used in this PKM uses an extension approach, mentoring through storytelling. The application of $3 \mathrm{M}$ begins with storytelling activities about the dangers of covid-19 using dolls (puppets). The next activity provided knowledge on how to wash hands with good and correct soap and hand washing practices after the counselling activity was carried out, and finally we carried out monitoring and evaluation to ensure the activity went well and smoothly. Thus, participants can easily understand the importance of maintaining $3 \mathrm{M}$ behaviour to break the chain of transmission of covid19 among students, especially female students in western region of the Nurul Jadid Islamic Boarding School, Paiton, Probolinggo.
\end{abstract}


Katakunci:

Literasi $3 \mathrm{M}$, Storytelling, Santriwati Nurul Jadid
Salah satu persoalan mendasar penyebab maraknya penyebaran Covid-19 di pondok pesantren adalah rendahnya kemampuan literasi saintifik para santri. Ketidakmampuan mereka memahami urgensi istilah-istilah sains menjadikan mereka abai, kurang memberi perhatian terhadap dirinya dan lingkungannya dalam menjaga kebersihan dan kesehatan, dan cenderung apatis terhadap berbagai pendekatan dalam penanganan Covid-19. Karena itulah, dibutuhkan pendekatan intens dan inovatif dalam memberikan edukasi kepada para santri untuk selalu mengingat $3 \mathrm{M}$ (Memakai Masker, Mencuci Tangan, Menjaga Jarak). Metode dalam PKM ini adalah pendekatan penyuluhan, pendampingan melalui storytelling. Subjek dampingan adalah para santriwati di Wilayah Barat Pesantren Nurul Jadid. Penerapan $3 \mathrm{M}$ ini dimulai dengan kegiatan mendongeng (storytelling) tentang bahaya Covid-19 dengan menggunakan boneka (puppet). Kegiatan selanjutnya adalah memberi pengetahuan cara mencuci tangan dengan sabun yang baik dan benar serta praktik cuci tangan setelah kegiatan penyuluhan dilakukan. Langkah terakhir adalah melakukan monitoring dan evaluasi untuk memastikan kegiatan berjalan dengan baik dan lancar. Hasil PKM ini adalah meningkatnya pemahaman mereka tentang pentingnya menjaga perilaku $3 \mathrm{M}$ untuk memutus mata rantai penularan covid 19

\section{Pendahuluan}

Pandemi (covid 19) di tahun 2021, yang disebabkan oleh virus SARSCoV-2 (Severe Acute Respiratory Syndrome Coronavirus-2) masih sangat tampak terasa dampak terhadap seluruh aspek kehidupan baik sektor pariwisata maupun perekonomian. Semua orang diwajibkan menerapkan protokol kesehatan 3M, yaitu memakai masker,mencuci tangan dengan sabun, dan menjagajarak. Penerapan aturan ini harus terus dijaga dalam setiap rutinitas kita, baik di dalam maupun di luar rumah. Menurut(Yanti, Nugraha, Wisnawa, Dian, \& Diantari, 2020), Pandemi COVID-19 (Coronavirus Disease2019) yang disebabkan oleh virus SARSCoV-2 (Severe Acute Respiratory Syndrome Coronavirus-2) menjadi peristiwa yang mengancam kesehatan santriwati secara umum dan telah menarik perhatian dunia. Oleh karena itu, penguatan protokol kesehatan harus tetap dijaga dengan selalu menerapkan protokol kesehatan 3 M. Wiku Adisasmito (Juru Bicara Satgas Penanganan COVID-19) menegaskan, bahwa

Santriwati diminta terus menerapkan protokol kesehatan 3M yaitu memakai masker, menjaga jarak dan mencuci tangan serta menjauhi 
kerumunan. Penerapan ini harus terus dijalankan dalam setiap kegiatan. Dan kedisiplinan menerapkan protokol kesehatan 3M merupakan kontribusi santriwati terhadap upaya penangan COVID-19 yang dilakukan pemerintah. "Ingat, dengan kita disiplin, maka tidak saja melindungi diri sendiri, dan melindungi orang-orang terdekat(PEN KPC, 2020). Ini merupakan bentuk strategi terbaik pemerintah dalam mencegah dan mengendalikan menularan Covid-19 yang semakin hari semakin meningkat.

COVID-19 pertama dilaporkan di Indonesia pada tanggal 2 Maret 2020 sejumlah dua kasus(Susilo, et al., 2020). Jumlah Total kasus konfirmasi COVID-19 secara global wilayah Jawa timur per tanggal 18 Maret 2021 adalah 135.303 kasus dengan 9.578 kematian dan 124.044 sembuh(KemenKes RI, 2021). Hal ini tidak menutup kemungkinan bertambahnya orang yang akan terpapar virus corona di Jawa Timur tidak terkecuali para santri dipondok pesantren jika tidak tegas menjalankan protokol Kesehatan yang telah di perintahkan oleh pemerintah Indonesia yakni dengan mencuci tangan, memakai masker dan menjaga jarak.

Salah satu persoalan mendasar penyebab maraknya penyebaran covid 19 adalah rendahnya angka literasi sains di santriwati. Ketidakmampuan santriwati memahami urgensi istilah-istilah sains menjadikan mereka abai, kurangnya rasa kesadaran terhadap dirinya dan lingkungannya dalam menjaga kebersihan dan kesehatan dan serta cenderung apatis terhadap pendekatan-pendekatan guna pengentasan covid 19. Sebelumnya pemahaman akan istilah biologi, medis dan epidemologis merupakan hal yang bersifat opsional bagi tiap orangnya. Oleh karena itu, perlu adanya pendekatan yang intensif dan inovatif dalam memberikan edukasi kepada santriwati utamanya santriwati Wilayah Dalem Barat Pondok Pesantren Nurul Jadid untuk selalu mengingat $3 \mathrm{M}$ (Memakai masker, Mencuci tangan, Menjaga Jarak).

Pendekatan yang dilakukan untuk meningkatkan pemahaman dalam mengatasi pandemi saat ini yaitu melalui metode storytelling. Storytelling merupakan menyampaikan sebuah ekspresi tentang sebuah cerita baik cerita bergambar atau pun sebuah dongeng. Metode tersebut seringkali digunakan dalam meningkatkan motivasi dan rasa percaya diri siswa dalam belajar. Menurut (Setyarini, 2015), mengimplementasi Storytelling dalam pembelajaran dapat dijadikan salah satu alternatif dalam meningkatkan 
hasil pembelajaran bahasa Inggris. Hal ini dikarenakan model ini dapat menawarkan banyak kesempatan kepada siswa untuk berlatih berkomunikasi dalam bahasa Inggris. Storytelling juga merupakan metode yang dapat memberikan efek yang luar biasa kepada siswa dalam mengkhafal serta memahami suatu bahasa (Amelia \& Nurmaily, 2021). Dengan pendekatan inilah, Santriwati wilayah barat Pesantren Nurul Jadid mampu taat menjalankan protokol kesehatan melalui $3 \mathrm{M}$ (Memakai Masker, Mencuci Tangan, dan Menjaga Jarak) dalam pencegahan dan penanggulangan Coronavirus Desease (Covid 19) terutama di kalangan santri dan umumnya santriwati umum.

\section{Metode}

Literasi Penguatan 3 M (Memakai Masker, Mencuci Tangan, Dan Menjaga Jarak) Melalui Metode Storytelling Pada Santriwati Di Wilayah Dalem Barat Pesantren Nurul Jadid menggunakan metode pendekatan penyuluhan, pendampingan. Penerapan $3 \mathrm{M}$ ini dimulai dengan kegiatan mendongeng (storytelling) tentang bahaya covid 19 dengan menggunakan boneka (puppet). Kemudian kegiatan selanjutnya memberikan pengetahuan cara mencuci tangan dengan sabun yang baik dan benar serta praktik cuci tangan setelah kegiatan penyuluhan dilakukan, dan terakhir kami melakukan monitoring dan evaluasi untuk memastikan kegiatan berjalan dengan baik dan lancar.

Kegiatan ini dilaksanakan pada hari Rabu tanggal 21 tahun 2021 bertempat di Aula MTs Nurul Jadid. Kegiatan ini dimulai dari pukul 13.00 17.00 WIB dengan agenda 13-00 - 14.30 penyampaian materi dengan storytelling dan 15.15 - 17.00 wib kegiatan praktek dan penutup. Peserta penyuluhan santriwati yang tinggal di wilayah barat pesantren Nurul Jadid sebanyak 28 santriwati yang telah dipilih perwakilan sebanyak 2 orang dari masing-masing kamar. Pemilihan keterbatasan peserta ini dilakukan menjalankan sebagai salah satu peraturan pemerintah dalam mengurangi mobilitas seseorang dan pencegahan penularan Covid 19. 


\section{Hasil dan Pembahasan}

\section{Tahap Observasi Lapangan}

Kegiatan ini dimulai dengan pemberitahuan terlebih dahulu kepada Kepala Wilayah barat Pesantren Nurul Jadid, Paiton Probolinggo guna mendapatkan persetujuan dari Penanggungjawab kepala wilayah dalam melaksanakan penyuluhan Literasi Penguatan 3 M (Memakai Masker, Mencuci Tangan, Dan Menjaga Jarak) Melalui Metode Storytelling Pada Santriwati di Wilayah Dalem Barat Pesantren Nurul Jadid. Kegiatan ini juga ada rangkaian pembagian masker dan sosialisasi kepada santriwati wilayah barat pesantren Nurul Jadid dengan teknis mendatangi satu-persatu kamar santriwati demi guna mengurangi kerumunan. Hal ini dilakukan 2 minggu sebelum kegiatan dilaksanakan.

\section{Tahap Pelaksanaan Kegiatan}

Kegiatan ini dilaksanakan setelah mendapatkan ijin dari Kepala Wilayah Barat Pesantren Nurul Jadid, Paiton, Probolinggo. Agenda pertama adalah persiapan tempat penyuluhan Literasi Penguatan $3 \mathrm{M}$ (Memakai Masker, Mencuci Tangan, Dan Menjaga Jarak) Melalui Metode Storytelling Pada Santriwati di Wilayah Dalem Barat Pesantren Nurul Jadid.

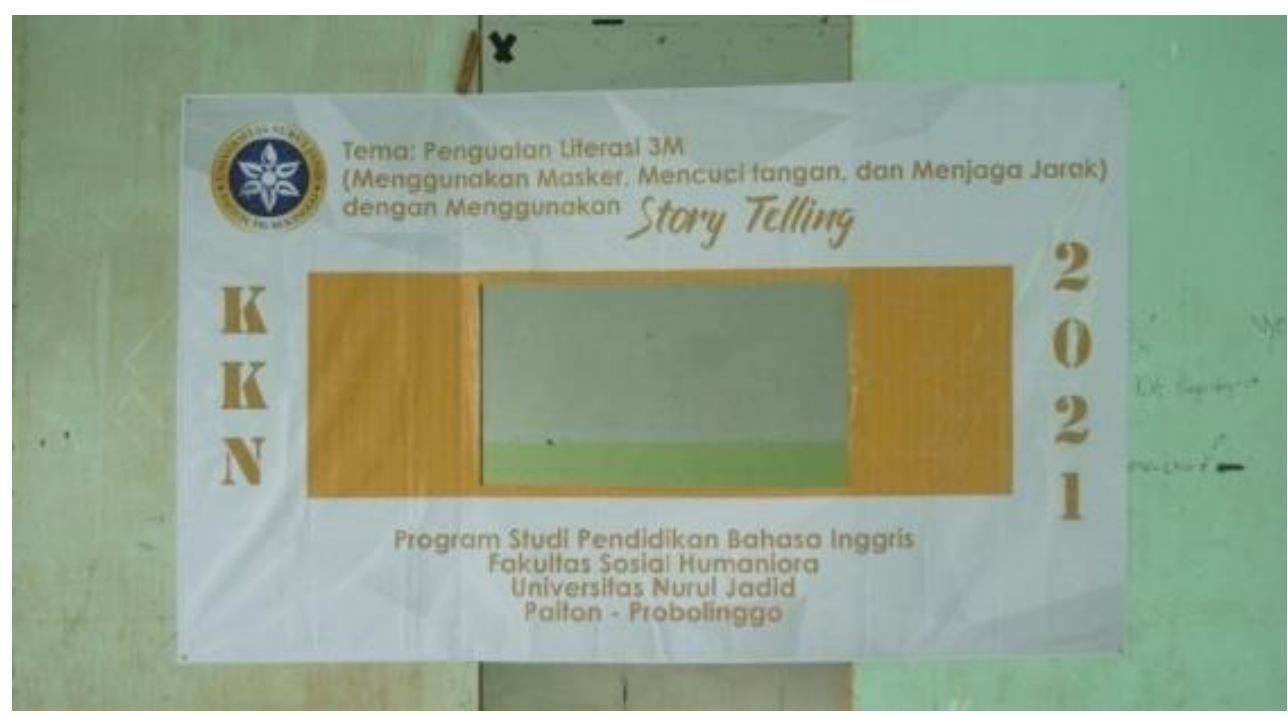

Gambar 1. Persiapan Penyuluhan Literasi Penguatan 3 M (Memakai Masker, Mencuci Tangan, dan Menjaga Jarak) Melalui Metode Storytelling 
Pada hari rabu tanggal 21 Maret 2021 kami melanjutkan kegiatan Pengabdian ini dengan kegiatan Penyuluhan Kesehatan untuk Literasi Penguatan 3 M (Memakai Masker, Mencuci Tangan, Dan Menjaga Jarak) Melalui Metode Storytelling kepada santriwati wilayah barat Pesantren Nurul Jadid yang telah dipilih secara acak sebanyak 28 santriwati. Dari terpilihnya santriwati ini nantinya bisa memberikan contoh nyata kepada santri-santri yang ada dilingkungan Pesantren Nurul Jadid. Peserta santriwati tersebut wajib menaati protokol kesehatan yakni wajib menggunakan masker, mencuci tangan dan jaga jarak (tempat duduk kami atur \pm 1 meter setiap peserta).

Pengaturan jarak peserta penyuluhan merupakan bagian dari protokol kesehatan yang ditetapkan oleh kementrian kesehatan RI. Hal ini mengajarkan peserta untuk selalu menjaga jarak antar peserta sebagai langkah pencegahan penularan virus covid 19. Selanjutnya peserta diberikan penjelasan tentang Pentingnya melaksanakan $3 \mathrm{M}$ (Memakai Masker, Mencuci Tangan, Dan Menjaga Jarak) dengan Storytelling (bercerita).

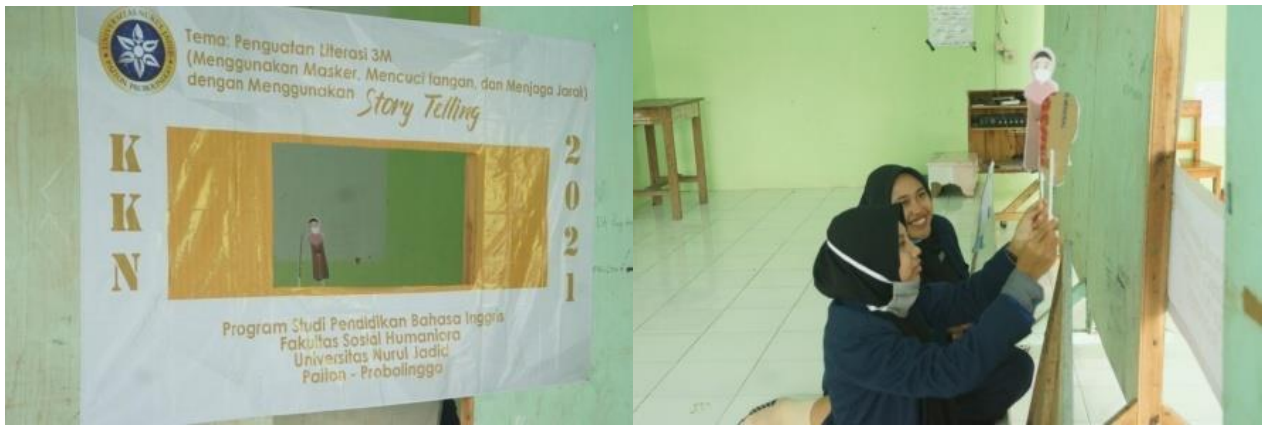

Gambar 2. Pemateri memberikan penyuluran tentang pentingnya memperkuat budaya 3 M (Memakai Masker, Mencuci Tangan, Dan Menjaga Jarak) dengan Storytelling (bercerita)

Pada kegiatan pengabdian ini pemateri memberi penjelasan dan edukasi kepada peserta dengan cara yang berbeda dalam penyampaiannya, yaitu dengan storytelling (bercerita). Cerita berjudul "Dinda si Kecil". Penyampaian cerita ini pemateri (mahasiswi pendidikan bahasa inggris) menggunakan media puppet (boneka) sebagai sarana penyampaian pesan yang inovatif dan menarik tingkat kesadaran pentingnya menjaga kebiasaan 3 M (Memakai Masker, Mencuci Tangan, Dan Menjaga Jarak) dikalangan 
santriwati pondok pesantren Nurul Jadid, Paiton, Probolinggo. Isi sebuah cerita ini memberikan pesan kepada semua orang dari mulai anak-anak sampai orang tua bahwa pada saat pandemi covid 19 ini semua orang harus patuh dan disiplin untuk selalu memakai masker, mencuci tangan dengan air mengalir atau menggunakan Handsinitizer, dan menjaga jarak di dalam dan diluar ruang.

Selanjutnya kegiatan pengabdian mempraktekkan cara mencuci tangan dengan lagu "senam cuci tangan". Berikut lirik lagu cuci tangan"

\author{
Mari mari mari menari \\ 6 langkah cuci tangan jadi kreasi \\ Hidup sehat lingkungan bersih \\ Jaga kebersihan tubuhpun jadi sehat \\ Mari mari mari menari \\ 6 langkah cuci tangan jadi kreasi \\ Satu dua tiga empat lima dan enam \\ 6 langkah cuci tangan mari beraksi \\ Gosok kedua telapak tangan \\ Secara lembut dengan arah memutar (2x) \\ Usap dan gosok juga kedua punggung tangan \\ Secara bergantian $(2 \mathrm{x})$ \\ Gosok sela-sela jari tangan \\ Hingga sungguh-sungguh bersih $(2 x)$ \\ Bersihkan ujung jari secara bergantian \\ Dengan posisi saling mengunci $(2 \mathrm{x})$ \\ Gosok dan putar kedua ibu jari \\ Secara bergantian $(2 x)$ \\ Letakkan ujung jari ketelapak tangan \\ Kemudian gosok perlahan $(2 x)$ \\ Bilas kembali tangan di bawah air mengalir \\ Hingga sungguh-sungguh bersih $(2 x)$
}

Hal ini dilakukan karena masih ada santri yang belum memahami 6 langkah cara mencuci tangan dengan baik dan benar. Melalui lagu senam cuci tangan akan membantu khususnya santriwati umumnya santri Pondok Pesantren Nurul Jadid mengerti dan paham cara mencuci tangan dengan cara-cara yang menyenangkan salah satunya dengan bernyayi. Pada 
kegiatan ini peserta diminta untuk bernyanyi dan mempraktekkan bersamasama.

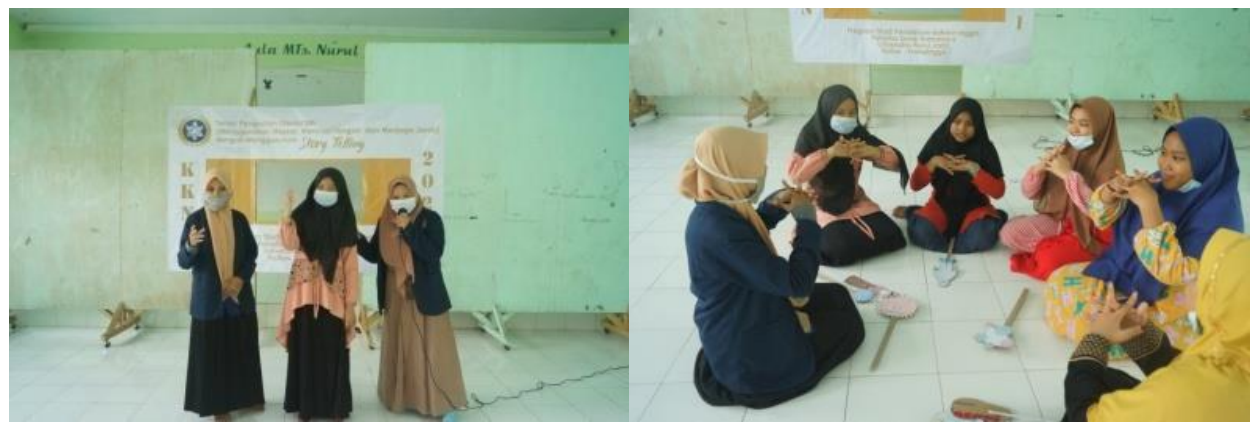

Gambar 3. Peserta bernyanyi lagu senam cuci tangan dan memperaktekannya

\section{Tahap Penutupan kegiatan}

Pukul 13.30 Wib acara penutupan kegiatan dengan melakukan dokumentasi bersama peserta penyuluhan santriwati wilayah barat Pondok pesantren Nurul Jadid dan juga memberikan cendramata berupa hand sanitizer dan masker serta berterimakasih kepada peserta penyuluhan yang telah antusias mengikuti acara penyuluhan tersebut.

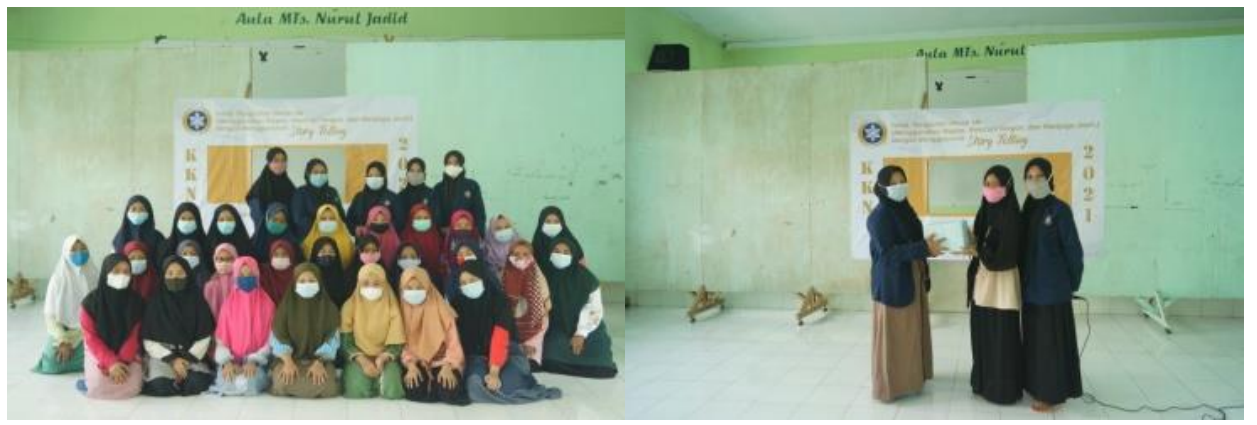

Gambar 4. Penyerahan Cindramata kepada peserta dalam Literasi Penguatan 3 M di Wilayah Barat Pesantren Nurul Jadid

Hasil yang diperoleh dari pengabdian kepada santriwati ini adalah memberikaan informasi dan edukasi pada santriwati tentang pentingnya penerapan 3M (memakai masker, menjaga jarak dan mencuci tangan) untuk pencegahan penularan virus corona di Pesantren Nurul Jadid khususnya di wilayah barat Pesantren Nurul Jadid. Dengan memperkuat pemahaman 3M 
sedini mungkin akan menambah dan memperkuat personal hygiene, mencuci tangan, memakai masker, dan menjaga jarak.

Memakai masker, menjaga jarak dan mencuci tangan dengan sabun dan air mengalir adalah kewajiban yang harus kita lakukan untuk menjaga kesehatan tubuh terutama di masa pandemi covid-19 saat ini guna untuk memutuskan mata rantai penularan covid-19 di wilayah Pesantren Nurul Jadid.

\section{Kesimpulan}

Perhatian dunia saat ini tertuju pada pandemi COVID-19 (Coronavirus Disease2019) yang disebabkan oleh virus SARSCoV-2 (Severe Acute Respiratory Syndrome Coronavirus-2) karena menjadi peristiwa yang mengancam kesehatan santriwati secara umum dan berdampak kepada semua sektor tidak terkecuali sektor perekonomian. Kegiatan Literasi penguatan 3M untuk pencegahan penularan virus corona di Wilayah Barat Pesantren Nurul Jadid adalah salah satu cara peningkatan pengetahuan dan pemahaman santri khususnya santriwati dalam hal pemutusan matarantai penularan covid-19. PKMini juga mendapatkan apresiasi yang baik dari peserta karena penyampaiannya menarik dan inovatif yakni dengan model storytelling (mendongeng).

\section{Pengakuan}

Ucapan terima kasih kepada segenap keluarga besar pesantren Nurul Jadid khususnya Pengasuh, Kepala Pesantren, Kepala Wilayah Barat Pesantren Nurul Jadid yang telah mendukung berjalannya pengabdian ini berjalan dengan lancar, serta santriwati yang berperan aktif dalam kegiatan ini. 


\section{Referensi}

Amelia, D., \& Nurmaily, E. (2021). Upaya Peningkatan Kosakata Bahasa Inggris Melalui Storytelling Slide and Sound. Journal Sosial Science and Teknology for Community Service (JSSTCS) , 23.

KemenKes RI, G. (2021, Maret 19). Situasi Terkini Perkembangan Coronavirus Disease (COVID-19) 19 Maret 2021. Retrieved Juni 15, 2021, from Media Informasi Resmi Terkini Penyakit Infeksi Emerging: https://infeksiemerging.kemkes.go.id/situasi-infeksi-emerging/situasiterkini-perkembangan-coronavirus-disease-covid-19-19-maret-2021

PEN KPC, T. K. (2020, November 5). Disiplin Jalankan Protokol Kesehatan Kunci Hindari Gelombang Kedua. Retrieved Juni 15, 2021, from Komite Penanganan Corona Virus Disease 2019 (COVID-19) dan Pemulihan Ekonomi Nasional: https://covid19.go.id/p/berita/disiplin-jalankanprotokol-kesehatan-kunci-hindari-gelombang-kedua

Setyarini, S. (2015). Pengembangan Model Pembelajaran Berbasis Storytelling: Sebuah Terobosan Dalam Upaya Meningkatkan Output Pembelajaran Bahasa Inggris Anak Usia Dini. Jurnal Penelitian Pendidikan LPPM Universitas Pendidikan Indonesia , 1.

Susilo, A., Rumende, C. M., Pitoyo, C. W., Santoso, W. D., Yulianti, M., Herikurniawan, H., et al. (2020). Coronavirus Disease 2019: Tinjauan Literatur Terkini. Jurnal Penyakit Dalam Indonesia , 45.

Yanti, N. P., Nugraha, I. M., Wisnawa, G. A., Dian, N. P., \& Diantari, N. P. (2020). Gambaran Pengetahuan Santriwati tentang Covid-19 dan Perilaku Santriwati di Masa Pandemi Covid-19. Jurnal Keperawatan Jiwa Volume 8 No 3, 491. 


\section{GUYUB}

\section{Journal of Community Engagement}

P-ISSN: 2723-1232

E-ISSN: 2723-1224

GUYUB: Journal of Community Engagement is is a multidisciplinary journal which aims to disseminate the conceptual thoughts and research results in the area of community service. This journal focuses on the main problems of the community engagement areas, such as (1) training, marketing, appropriate technology, design; (2) student community services; (3) community empowerment, social access; (4) education for sustainable development, etc.

GUYUB: Journal of Community Engagement is published three times a year (April, August, December) by Lembaga Penerbitan, Penelitian, dan Pengabdian kepada Masyarakat (LP3M) Universitas Nurul Jadid, Paiton, Probolinggo, Jawa Timur, Indonesia.

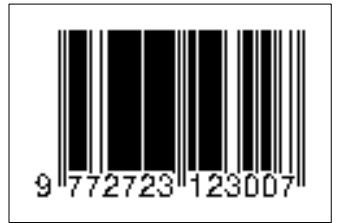

Editorial Office:

GUYUB: Journal of Community Engagement

Lembaga Penerbitan, Penelitian, dan Pengabdian kepada Masyarakat

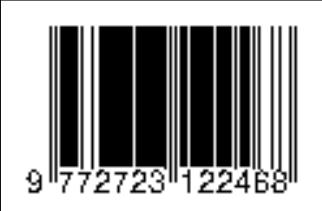

(LP3M) Universitas Nurul Jadid, Probolinggo, Jawa Timur, Indonesia 67291.

Phone: 088830 77077, Hp: 082318007953

Email: jurnal.guyub@gmail.com

Website: https://ejournal.unuja.ac.id/index.php/guyub/index 